\title{
ISLAM NUSANTARA: SEBUAH ARGUMENTASI BERAGAMA DALAM BINGKAI KULTURAL
}

\author{
Hanum Jazimah Puji Astuti \\ Mahasiswa Pasca Sarjana IAIN Salatiga \\ hanum.enyum90@gmail.com
}

\begin{abstract}
The emergence of Islam Nusantara is the typical of Indonesia, where Islam Nusantara is declared as a universal religion, manifested in its teachings including religious law (figh), trust (faith), and the ethical (the moral). Although Islam Nusantara gives a new ambience in Islam by assimilating a culture into religion, this method is not contagious to the purity of Islamic teachings by taking Quran and Hadith as the guidances and directions in the Indonesian social life. Islam teaches mutual respect and reciprocal tolerance. This religion teaches the adherents to love others, to mercy and nurture regardless of race, nationality, and social structure. This is in line with the Indonesian Islam commonly called 'Islam Nusantara'. It can be said that someone who lived in the religion, including people that comprehend the religion intrinsically, occupies religion as a guide of life, applies and practices based on the belief. At the social level, religious values serve as the basis for adopting a life policy.
\end{abstract}

Keywords: $\quad$ Islam Nusantara, universal, cultural and intrinsic

\begin{abstract}
Abstrak
Pemunculan Islam Nusantara merupakan ciri khas Indonesia, di mana Islam Nusantara ini di nyatakan sebagai agama yang universal, dimanifestasikan dalam ajarannya, yang mencakup hukum agama (fiqh), kepercayaan (tauhid), serta etika (akhlak). Meskipun Islam Nusantara memberikan nuansa baru dalam beragama Islam dengan memasukkan budaya dalam agamanya, namun cara beragama seperti ini tidak menghilangkan kemurnian ajaran Islam itu sendiri, dengan menjadikan al Quran dan Hadits sebagai pedoman dan tuntunan dalam kehidupan sosial masyarakat Indonesia. Dalam beragama, Islam mengajarkan untuk saling menghargai dan saling toleransi, agama yang mengajarkan penganutnya untuk saling menyayangi, mengasihi dan mengayomi tanpa memandang ras, kebangsaan, serta struktur sosial. Hal ini sejalan dengan Islamnya Indonesia yang biasa disebut 'Islam Nusantara'. Dapat dikatakan seseorang yang menjalani agama itu, termasuk orang yang menghayati agamanya dengan cara intrinsik, agama dijadikan sebagai pedoman hidup, dijalankan dan diamalkan sesuai dengan keyakinannya. Pada tataran sosial nilai-nilai agama dijadikan sebagai dasar dalam mengambil kebijakan hidup.
\end{abstract}

Kata kunci: Islam Nusantara, universal, budaya dan intrinsik 
INJECT: Interdisciplinary Journal of Communication, Vol.2, No.1, Juni 2017: h. 27-52

\section{Pendahuluan}

Islam adalah sebuah risalah yang telah dikirim ke seluruh umat manusia tanpa memandang ras mereka, kebangsaan, serta struktur sosial (al-Islam salih likulli zaman wa makan). Islam tidak dikirim ke negara tertentu, komunitas yang dipilih, sehingga orang lain harus mematuhi mereka. Risalah Islam adalah panduan dan rahmat untuk seluruh umat manusia, seperti yang telah dijelaskan dalam al-Qur'an shurah al-Anbiya ayat 107, yang artinya: "Dan tiadalah kami mengutus kamu, melainkan untuk (menjadi) rahmat bagi semesta alam. Dalam Q.S. al-Anbiya: 107, jelas bahwa Islam adalah agama belas kasihan bagi semua makhluk (manusia, hewan, tumbuhan, dan semua makhluk). Ini berarti bahwa Islam adalah agama universal, universalisme ini telah dimanifestasikan dalam ajarannya, yang mencakup hukum agama (fiqh), kepercayaan (tauhid), serta etika (akhlak). Oleh karena itu, semua umat Islam benar-benar percaya bahwa Islam sesuai bagi semua makhluk. It means that Islam is a universal religion, this universalism has been manifested in its teachings, which covers religious laws (fiqh), belief (tauhid), as well as ethics (akhlak). For that reason, all moslems were totally believe that Islam would suitable for all ages and places as the guidance for all creatures (Nur Sahid, 2016:3).

Melihat dari pernyataan di atas sudah jelas, bahwa agama Islam adalah agama yang sangat menghargai dan saling toleransi, agama yang mengajarkan penganutnya untuk saling menyayangi, mengasihi dan mengayomi tanpa memandang ras mereka, kebangsaan, serta struktur sosial. Hal ini sejalan dengan Islamnya Indonesia yang biasa disebut 'Islam Nusantara'. Meskipun bukan negara Islam, namun penduduk Indonesia mayoritas beragama Islam. Indonesia merupakan negara yang tidak begitu terpengaruh dengan arabisasi, sebab masyarakat Indonesia adalah masyarakat yang multikultural, masyarakat yang menjunjung nilai-nilai kebudayaan. Namun, tidak berarti Islam yang mereka anut menyimpang dari kemurnian ajaran Islam itu sendiri. 
Masyarakat Indonesia dikatakan multikultural karena konsep ini mengedepankan budaya. Sehingga ketika mendengar istilah Islam Nusantara, maka akan berkaitan dengan pluralitas. Dalam Islam Nusantara, budaya merupakan bagian dari agama, di mana awal mula Islam dapat dengan mudah diterima di Indonesia salah satunya melalui akulturasi budaya, sehingga agama Islam terkesan merakyat dengan masyarakat Indonesia.

Dalam pluralitas dan kebeagamaan antara umat dan bangsa-bangsa dalam kerangka kesatuan manusia, filsafat ini mencetak peradaban Islam dengan ciri yang moderat, menyelaraskan antara kekhasan individual yang dimiliki oleh masing-masing umat dan bangsa, dengan keutamaan atau keburukan yang terjadi pada semua umat dan bangsa. Maka, yang terjadi kemudian adalah rasa bangga terhadap kekhasan dan keutamaan yang dimiliki tanpa mengingkari kekhasan dan kelebihan yang lain. Sikap ini tampak dalam peradaban Islam. Sehingga, hal itu dapat mengalahkan kecenderungan fanatisme non-Arab dan fanatisme kekabilahan Arab seluruhnya (Imarah, 1997:141). Kajian menarik dari Islam Nusantara adalah platform untuk menegaskan kembali bahwa Islam di negeri ini mengadaptasi nilai-nilai lokal yang menjadi ciri khasnya. Warisanwarisan ulama, menjadi bagian penting dari transformasi keilmuan Islam Nusantara (Mizan, 2016:9).

Ekspresi Islam Nusantara dihadirkan terkait dengan kenyataan bahwa, berkat dinamika tersebut, budaya nusantara mengembangkan ciri-ciri yang khas, yakni unsur-unsur yang menekankan pada kedamaian, harmoni dan silaturahim (kerukunan dan welas asih), yang sebenarnya hanya merupakan manifestasi dari inti ajaran Islam itu sendiri. Memang, kenyataan ini disumbang baik oleh budaya khas nusantara pra-Islam maupun oleh kenyataan bahwa Islam yang dihayati oleh mayoritas Muslim di negeri ini didasarkan pada wasatiyah (modernisasi), tawazun (keseimbangan) dan tasamuh (toleransi) (Mizan, 2016:10). 
Islam yang selama ini orang jalani ternyata menjadi unik dan menarik setelah maraknya fenomena keberagamaan kelompok di luar yang menamakan diri muslim dan membawa bendera Islam, namun membuat gelisah dunia. Dunia yang kemudian bertanya-tanya tentang Islam yang rahmatan lil'aalamin, Islam yang ramah, damai, dan teduh pun mendapatkan jawaban dari perilaku keislaman kita yang ada di nusantara ini. Maka kalau 'Islam kita' Islam yang dijalani di nusantara ini ternyata dapat membantu peradaban tidak hanya di Indonesia tapi dunia. Tapi harus realistis, perilaku keislaman itu sendiri saat ini, sudah mulai terganggu oleh berbagai pengaruh dari luar. Sebagai bangsa Indonesia yang beragama Islam sudah barang tentu ikut memperkokoh dan mempertahankan cara kita berIslam selama ini, seperti yang diajarkan oleh guru-guru Islam yang memperoleh Islam dari guru-guru mereka dari guru-guru sebelumnya dengan sanad yang bersambung hingga Rasulullah saw (Bisri, 2016:14).

Agama (Islam) bersumberkan wahyu dan memiliki norma-normanya sendiri. Karena bersifat normatif, maka ia cenderung menjadi permanen. Sedangkan budaya adalah buatan manusia, karenanya ia berkembang sesuai dengan perkembangan zaman dan cenderung untuk selalu berubah. Perbedaan ini tidak menghalangi kemungkinan manifestasi kehidupan beragama dalam bentuk budaya. Maka muncul istilah seudati cara hidup santri, budaya menghormati kiai dan sebagainya, dengan wawasan budaya dari agama secara langsung diterima dan dilaksanakan oleh masyarakat tanpa mempersoalkan dalilnya. Umat Islam abangan yang menjahui malima, madat atau mengonsumsi obat-obat terlarang, madon atau main perempuan, mabuk, maling, main atau berjudi) belum tentu dengan alasan keagamaan, tetapi sangat boleh jadi karena alasan-alasan budaya, misalnya ketaatan kepada kiai atau orangtua (Wahid, 2016:33).

Akulturasi antara agama dan budaya akan terjadi terus-menerus sebagai suatu proses yang akan memperkaya kehidupan dan membuatnya 
tidak gersang, kekayaan variasi budaya akan memungkinkan adanya persambungan antara berbagai kelompok atas dasar persamaan-persamaan, baik persamaan agama maupun budaya. Upaya rekonsiliasi antara budaya dan agama bukan karena kekhawatiran terjadinya ketegangan antara keduanya, sebab kalau manusia dibiarkan pada fitrah rasionalnya, ketegangan seperti itu akan reda dengan sendirinya (Wahid, 2016:34).

Bahaya dari proses arabisasi atau proses mengidentifikasikan diri dengan budaya Timur Tengah adalah tercabutnya seorang muslim dari akar budaya sendiri. Lebih dari itu, arabisasi belum tentu cocok dengan kebutuhan. Pribumisasi bukan upaya menghindarkan timbulnya perlawanan dari kekuatan-kekuatan budaya setempat, akan tetapi justru agar budaya ini tidak hilang. Inti pribumisasi Islam adalah kebutuhan, bukan untuk menghindari polarisasi antara agama dengan budaya, sebab polarisasi demikian memang tak terhindarkan.

Sebagai titik tolak dari upaya rekonsiliasi ini adalah meminta agar wahyu dipahami dengan mempertimbangkan faktor-faktor kontekstual, termasuk kesadaran hukum dan rasa keadilannya. Dalam proses ini pembaruan Islam dengan budaya tidak boleh terjadi, sebab berbaur berarti hilangnya sifat-sifat asli. Islam harus tetap pada sifat Islamnya. al-Qur'an adalah harus tetap dalam bahasa Arab, terutama dalam salat, sebab hal ini telah merupakan norma. Sedang terjemahan al-Qur'an hanyalah dimaksudkan untuk mempermudah pemahaman, bukan menggantikan al-Qur'an sendiri (Wahid, 2016:35).

\section{Konsep dan Masuknya Islam ke Nusantara}

Ide Islam Nusantara bukan untuk mengubah doktrin Islam. Ia hanya ingin mencari cara bagaimana melabuhkan Islam dalam konteks budaya masyarakat yang beragam. Upaya itu dalam ushul fiqh disebut dengan ijtihad tathbiqi, yaitu ijtihad untuk menerapkan hukum. Sebab, Islam nusantara tak banyak bergerak pada aspek ijtihad istinbathi, yaitu 
ijtihad untuk menciptakan hukum. Imam al-syathibi membedakan ijtihad tathbiqhi dan ijtihad istinbathi. Menurutnya, jika ijtihad istinbathi tercurah pada bagaimana menciptakan hukum (insya' al-hukum), maka ijtihad tathbiqi berfokus pada aspek penerapan hukum (tathbiq wa tanzil al-hukm) (Ghazali, 2016:106).

Agama adalah ciptaan Allah SWT yang konstan. Esensinya adalah tauhid uluhiyah dan mengesakannya dalam beribadah, mensyukuri nikmat-nikmat dengan melakukan amal saleh, serta beriman kepada kebangkitan, hisab dan balasan atas amal setelah kehidupan di dunia ini. Karena Allah SWT adalah Esa dan karena agama adalah ketetapan Illahi maka agama Allah SWT adalah satu. Diawali dari risalah-risalah agama sejak Nabi Adam hingga Nabi Muhammad saw.

Agama Illahi yang satu ini adalah Islam, artinya, taat kepada Allah SWT dan menyerahkan serta menundukkan wajah kepada-Nya dalam ketetapan-ketetapan yang telah diturunkan oleh-Nya yang dijadikan perangkat beragama oleh manusia, tauhid uluhiyah serta memurnikan ibadah hanya kepada Allah SWT semata, dan melakukan amal saleh, yang akan dihisab dan diberikan balasan nanti pada hari pembangkitan kembali. Dalam kerangka Illahi yang satu ini dan melalui risalah-risalah para rasul, serta perbedaan umat-umat yang menerima risalah pada zaman, tempat, kemaslahatan, tradisi, budaya, serta tingkatan kemajuannya, maka terjadilah banyak agama dan syari'at, yang merupakan jalan-jalan, petunjuk serta metode yang ditempuh oleh seluruh pemilik risalah dan pemeluk setiap agama untuk beragama dengan akidah-akidah yang konstan, agama Illahi yang tunggal ini.

Hakikat agama ini diperkuat oleh al-Qur'an, kitab suci yang menyempurnakan agama yang datang dengan syari'at penutup dan universal, serta elemen yang menyempurnakan bangunan yang berdiri di atas akidah yang sama, yang dikenal oleh seluruh risalah langit yang dikirim kepada umat manusia. Seperti yang dijelaskan dalam Q.S Al- 
hajj: 77-78 "Hai orang-orang yang beriman, rukuklah kamu, sujudlah kamu, sembahlah Tuhanmu, dan perbuatlah kebajikan, supaya kamu mendapat kemenangan. Dan, berjihadlah kamu pada jalan Allah dengan jihad yang sebenarbenarnya. Dia telahmemilih kamu dan Dia sekali-kali tidak menjadikan untuk kamu dalam agama suatu kesempitan. (Ikutilah) agama orang tuamu Ibrahim. Dia (Allah) telah menamai kamu sekalian oran-orang muslim dari dahulu, dan (begitu pula) dalam (al-Qur'an) ini, supaya Rasul itu menjadi saksi atas dirimu dan supaya kamu semua menjadi saksi atas segenap manusia maka dirikanlah sembahyang, tunaikanlah zakat, dan berpeganglah kamu pada tali Allah. Dia adalah Pelindungmu maka Dialah sebaik-baik Pelindung dan sebaik-baik Penolong" (Imarah, 1997:73).

Dari konteks di atas dapat dilihat meskipun Islam Nusantara mengedepankan budaya atau memberikan nuansa baru dalam beragama Islam. Namun, sama sekali tidak merubah kemurnian ajaran Islam itu sendiri, tidak melakukan penyimpangan-penyimpangan dalam beragama. Justru dengan Islam Nusantara, penganut ajaran Islam terkesan tidak kaku dan lebih humble.

Kaitannya dengan hal tersebut, Islam Nusantara memiliki unsur intrinsik dalam memahami ajaran agamanya, seperti dalam bukunya Raymond F. Paloutzian yang berjudul "Psychology of Religion" yang menjelaskan: Intrinsically motivated people tend to agree with statements such as: "I try hard to carry my religion over into all my other dealings in life": "My religious beliefs are what lie behind my whole approach to life": "The prayers I say when I am alone carry us much meaning and personal emotion as those said by me during services" (Paloutzian, 1996:201). Dalam konteks ini orang yang menganut ajaran tersebut termasuk orang yang beragama secara instrinsik, dengan beragama secara intrinsik maka agama dianggap menunjang kesehatan jiwa dan kedamaian masyarakat, agama dipandang sebagai sebuah komitmen yang komprehensif, dan menjadi langkah dan motivasi hidup sesuai dengan agama, yang mengatur seluruh hidup 
seseorang. Agama diterima sebagai faktor pemandu. Cara beragama seperti ini terhujam ke dalam diri penganutnya. Hanya dengan cara itu mereka mampu menciptakan lingkungan yang penuh kasih sayang.

Dalam pandangan seseorang yang menjalani agama dengan cara intrinsik, agama dijadikan sebagai pedoman hidup, dijalankan dan diamalkan sesuai dengan keyakinannya. Pada tataran sosial nilai-nilai agama dijadikan sebagai dasar dalam mengambil kebijakan hidup. Bisa saja seseorang tersebut tidak glamor dengan atribut keagamaan. Tetapi secara subtantif dia mengamalkan nilai-nilai keagamaan yang dianutnya secara jujur dan apa adanya.

Dalam persfektif agama Islam beragama semacam ini di identikan dengan sikap amal sholeh. Orang yang beramal sholeh mampu menginternalisai nilai-nilai agama kedalam ranah kesadaran spritual dan sosial. Islam datang ke Nusantara sebagai agama yang universal, sempurna, lentur, elastis dan selalu dapat menyesuaikan dengan situasi dan kondisi memberikan dampak yang sangat signifikan bagi kehidupan masyarakat Indonesia, Islam terus merambat kesemua penjuru bumi nusantara mengakibatkan bumi nusantara dianggap sebagai suatu negeri yang sangat kaya dengan budaya. Alasannya, secara ilmiah kehidupan agama dan budaya sedang memberi suatu ekspose tentang seluk beluk yang mendasar. Islam dikenal sebagai salah satu agama yang akomodatif terhadap tradisi lokal dan ikhtilaf ulama dalam memahami ajaran agamanya Islam dibawa oleh Nabi Muhammad SAW. kepada seluruh manusia dalam segala aspek kehidupan, termasuk dalam bidang sosial politik. Beliau membebaskan manusia dari kegelapan peradaban menuju cahaya keimanan (Abidin, 2017:1).

Islamisasi merupakan suatu proses yang sangat penting dalam sejarah di Indonesia dan juga hal yang paling tidak jelas. Ketidakjelasan ini terletak pada pertanyaan kapan Islam datang, dari mana Islam berasal, siapa yang menyebarkan Islam pertama kali di Indonesia. Metamorfosa 
perkembangan Islam pada masa awal di Indonesia selalu menarik untuk dikaji dan diteliti. Hal tersebut dikarenakan Islam yang hadir di perairan nusantara ini mampu dengan cepat beradaptasi sehingga tidak memunculkan benturan budaya dengan adat dan tradisi lokal yang sudah ada sebelumnya (Karim, 2007:323).

Tentang masuknya Islam di Indonesia ada pendapat dari para ahli sejarah. Sebagian ahliberpendapat bahwa kedatangan Islam pertama-tama ke Indonesia sudah sejak abad pertama Hijriah atau abad ke ke-7 M, dan sebagian lagi berpendapat bahwa Islam baru datang pada abad ke-13 M, terutama di Samudra Pasai. Ada beberapa teori tentang masuknya Islam di Indonesia. Pertama, Teori Gujarat. Teori ini dinamakan teori Gujarat bertolak dari pandangan yang menyatakan asal Negara membawa agama Islam ke Nusantara dari Gujarat. Adapun peletak dasar teori ini adalah Snouck Hurgronje, dalam bukunya L'Arabie et lesIndes Neerlandaises atau Revue de l'histoire des Religious. Snouck Hurgronje lebih menitikberatkan pandangannya ke Gujarat berdasarkan pada; a) kurangnya fakta yang menjelaskan peranan bangsa Arab dalam menyebarkan agama Islam ke Nusantara; b) hubungan dagang Indonesia-India telah terjalin lama; c) inkripsi tertua tentang Islam terdapat di Sumatera memberikan gambaran antara hubungan antara Sumatera dengan Gujarat (Dalimunthe, 2016:117). Sejalan dengan pemikiran Snouck Hurgronje, Moquette seorang sarjana Belanda lainnya juga berkesimpulan, bahwa tempat asal Islam di Nusantara adalah Gujarat. Ia mendasarkan kesimpulan ini setelah mengamati bentuk nisan di Pasai, kawasan utara Sumatera, khususnya yang bertanggal 17 Dzu Al-Hijjah 831 H/ 27 September 1428. Batu nisan yang kelihatannya mirip dengan batu nisan lain yang ditemukan di makam Maulana Malik Ibrahim (w. 822/1419) di Gresik, Jawa Timur ternyata sama bentuknya denggan batu nisan yang terdapat di Cambay, Gujarat. Berdasarkan contoh-contoh batu nisan ini ia berkesimpulan, bahwa batu nisan di Gujarat dihasilkan bukan hanya untuk pasar lokal, tetapi juga untuk diimpor ke kawasan lain, termasuk Sumatera dan Jawa. 
Selanjutnya, dengan mengimpor batu nisan dari Gujarat, orang-orang Nusantara juga mengambil Islam dari sana (Azra, 1995:24). Teori kedua, datang dari Arnold yang mempunyai pandangan, para pedagang Arab juga menyebarkan Islam ketika mereka dominan dalam perdagangan Barat-Timur sejak abad-abad awal hijri atau abad ke-7 dan ke-8 Masehi. Meskipun tidak terdapat catatan-catatan sejarah tentang kegiatan mereka dalam penyebaran Islam, cukup pantas mengasumsikan bahwa mereka terlibat pula dalam penyebaran Islam kepada penduduklokal di Nusantara. Asumsi ini menjadi lebih mungkin, ketika mempertimbangkan fakta yang disebutkan sumber-sumber Cina, bahwa menjelang akhir perempatan abad ke-7 seorang pedagang Arab menjadi pemimpin sebuah pemukiman Arab Muslim di pesisir pantai Sumatera. Sebagian orang-orang Arab ini dilaporkan melakukan perkawinan dengan wanita lokal, sehingga membentuk sebuah komunitas Muslim yang terdiri dari orang-orang Arab pendatang dan penduduk lokal (Azra, 1995:25).

Berdasarkan uraian tersebut mengenai masuknya Islam di Indonesia terjadi perbedaan pendapat, yakni abad ke-1 H/7 M dan abad ke-13 M. Masuk dan berkembangnya Islam di Nusantara melalui proses waktu yang panjang. Namun secara garis besarnya Azyumardi Azra mengemukakan pendapat dalam bukunya M. Abdul Karim yang berjudul Sejarah Pemikiran dan Peradaban Islam menyatakan, (Karim,2007:326) ada empat tema pokok yang berkaitan dengan permulaan penyebaran Islam di Nusantara yaitu; pertama, Islam dibawa langsung dari Arab; kedua, Islam diperkenalkan oleh para guru dan penyiar profesional (maksudnya, mereka yang khusus bermaksud menyebarkan Islam semacam zondiq); ketiga, pihak yang mulamula masuk Islam adalah penguasa. Kemudian keempat, mayoritas para penyebar Islam profesional ini datang di Nusantara pada abad ke-12 dan abad ke-13. Selanjutnya Azra menyatakan bahwa meskipun Islam sudah diperkenalkan ke Nusantara sejak abad Pertama Hijriah, namun hanya setelah abad ke-12 M pengaruh Islam tampak lebih nyata, dan proses Islamisasi baru mengalami akselerasi antara abad ke-12 dan $16 \mathrm{M}$. 


\section{Islam Nusantara dan Budaya Lokal}

Upaya pemaknaan memberikan kontribusi yang besar bagi upaya memahami hakekat Islam nusantara. Sebagai hakekat, sulit dipahami tanpa mengetahui ciri atau karakteristiknya. Selanjutnya makna tersebut memberikan pemahaman awal pada seseorang yang berusaha memahami substansinya. Dengan kata lain, makna Islam Nusantara berfungsi membuka jalan awal bagi pemahaman seseorang dalam menggali dan mengkaji pemikiran, pemahaman dan pengamalan ajaran-ajaran Islam yang mencerminkan dan dipengaruhi oleh kawasan ini (Qomar, 2016:200).

Mengingat pentingnya peranan agama tersebut maka agama perlu diketahui, digali, dipahami serta diamalkan oleh setiap pemeluk agama. Hal ini khususnya pemeluk agama Islam, sehingga nantinya akan benarbenar menjadi milik dan kepribadian dalam kehidupan sehari-hari. Salah satu usaha untuk mencapai hal tersebut dengan melalui pendidikan yaitu pendidikan agama Islam. Melalui pendidikan manusia disuruh untuk berfikir, menggunakan akal sesuai dengan fungsinya guna mencapai pengetahuan yang benar. Adapun cara pendidikan untuk menanamkan dalam diri anak-anak nilai-nilai agama dan budaya islami yang benar, pendidik juga harus mengajarkan anak-anaknya moral Islami dan memberitahukan kepada mereka ketentuan-ketentuan syariat agama. (Zuhaili, 2002:64) Masyarakat juga kerkewajiban memberikan pendidikan bagi anggotanya atau biasa disebut pendidikan yang bersifat informal, karena di masyarakatlah anak-anak melihat, meniru dan mencontoh apa yang dilakukan oleh orang-orang disekitarnya. Jika contoh yang diberikan oleh masyarakat itu baik dan positif, maka generasi mudanya akan terpengaruh berperilaku dan berkepribadian baik pula. Memang diakui bahwa pengaruh masyarakat berperan besar dalam pembentukan kepribadian anak. (Wahjoeutomo, 1979:42) Disamping masyarakat, sekolah-sekolah dan lembaga sosial yang memberikan pendidikan harus memperhatikan pembinaan agama pada anak didiknya. 
Islam nusantara adalah Islam yang khas ala Indonesia, gabungan nilai Islam teologis dengan nilai-nilai tradisi lokal, budaya, dan adat istiadat di Tanah Air. Karakter Islam Nusantara menunjukkan adanya kearifan lokal di Nusantara yang tidak melanggar ajaran Islam, namun justru menyinergikan ajaran Islam dengan adat sitiadat lokal yang banyak tersebar di wilayah Indonesia. Kehadiran Islam tidak untuk merusak atau menantang tradisi yang ada. Sebaliknya, Islam datang untuk memperkaya dan mengislamkan tradisi dan budaya yang ada secara tadriji (bertahap). Bisa jadi butuh waktu puluhan tahun atau beberapa generasi. Pertemuan Islam dengan adat dan tradisi Nusantara itu kemudian membentuk sistem sosial, lembaga pendidikan (seperti pesantren) serta sistem kesultanan. Tradisi itulah yang kemudian disebut dengan Islam Nusantara, yakni Islam yang telah melebur dengan tradisi dan budaya nusantara (Bizawie, 2016:240).

Islam Nusantara adalah Islam yang ramah, terbuka, inklusif dan mampu memberi solusi terhadap masalah-masalah besar bangsa dan negara. Islam yang dinamis dan bersahabat dengan lingkungan kultur, sub-kultur dan agama yang beragam. Islam bukan hanya cocok diterima oleh Nusantara, tetapi juga pantas mewarnai budaya Nusantara untuk mewujudkan sifat akomodatifnya yakni rahmatan lil 'alamin (Bizawie, 2016:240). Oleh karena itu, Islam nusantara ini merupakan cara melaksanakan Islam melalui pendekatan kultural, sehingga merawat dan mengembangkan budaya (tradisi) lokal yang sesuai dengan ajaran Islam, dan berusaha mewarnai budaya (tradisi) lokal itu dengan nilai-nilai Islam manakala budaya (tradisi) tersebut masih belum senafas dengan Islam. Islam sangat menghargai kreasi-kreasi kebudayaan masyarakat, sejauh tidak menodai prinsip prinsip kemanusiaan, ia tetap dipertahankan. Namun, jika budaya (tradisi) itu mencederai martabat kemanusiaan, ia harus ditolak. Maka Islam nusantara ini tidak menghamba pada tradisi karena tidak kebal kritik. Hanya tradisi yang menghormati nilainilai kemanusiaan yang perlu dipertahankan. Mekanisme kerja Islam Nusantara ini melalui pendekatan adaptif selektif dengan menggunakan 
filter yang ketat terhadap budaya (tradisi) lokal yang telah mengakar di masyarakat. Dengan pendekatan ini, Islam diharapkan berperan aktif mempengaruhi budaya maupun tradisi lokal tersebut.

Menyimak wajah Islam di dunia saat ini, Islam nusantara sangat dibutuhkan, karena ciri khasnya mengedepankan jalan tengah karena bersifat tawasut (moderat), tidak ekstrem kanan dan kiri, selalu seimbang, inklusif, toleran dan bisa hidup berdampingan secara damai dengan penganuut gama lain, serta bisa menerima demokrasi dengan baik. Model Islam nusantara itu bisa dilacak dari sejarah kedatangan jaran Islam ke wilayah Nusantara yang disebutnya melalui vernakularisasi dan diikuti proses pribumisasi, sehingga Islam menjadi embedded (tertanam) dalam budaya Indonesia (Azra, 1995: 2-15). Oleh karena itu, sudah selayaknya Islam nusantara dijadikan alternatif untuk membangun peradaban dunia Islam yang damai dan penuh harmoni di negeri mana pun, namun tidak harus bernama dan berbentuk seperti Islam nusantara karena dalam Islam nusantara tidak mengenal menusantarakan Islam atau nusantarasasi budaya lain (Bizawie, 2016:241).

Melalui citra Islam nusantara semestinya dapat menyadarkan masyarakat bahwa perbedaan merupakan anugerah yang telah Allah ciptakan. Ibarat musik, ketika bermacam-macam alat musik tersebut diperdengarkan sesuai dengan iramanya, maka akan menimbulkan suara yang sangat indah dan menimbulkan kepuasan bagi pendengarnya. Sama halnya ketika perbedaan tadi dianggap anugerah maka akan mewujudkan masyarakat yang saling menghargai, mengasihi, melindungi, memahami dan saling mempercayai bahwa keragaman dan perbedaan tidak menjadikan bangsa terkotak-kotak dan terpecah pelah. Inilah prinsip dan tujuan dari Islam Nuasantara, menciptakan kehidupan yang harmonis sesuai dengan kaidah Islam rahmatan lil 'alamin.

Bentuk operasionalisasi Islam nusantara adalah proses perwujudan nilai-nilai Islam melalui (bentuk) budaya lokal. Dalam tataran praksisnya, 
membangun Islam nusantara adalah menyusupkan nilai Islami di dalam budaya lokal atau mengambil nilai Islami untuk memperkaya budaya lokal atau menyaring budaya agar sesuai Islam (Bizawie, 2016:243).

Secara etimologis, Nusantara berasal dari bahasa sansekerta yang terdiri dari dua kata: Nusa dan Antara. Nusa berarti pulau, tanah air. Antara berarti jarak, sela, selang di tengah-tengah dua benda. Nusantara adalah pulau-pulau yang terletak antara Benua Asia dan Australia, diapit oleh dua lautan, Hindia dan pasifik. Karenanya, tidak salah jika Radhar Panca Dhana menyatakan bahwa orang-orang Nusantara adalah bangsa bahari yang inklusif. Islam bukan hanya cocok diterima orang Nusantara, tetapi juga pantas mewarnai budaya Nusantara untuk mewujudkan sifat akomodatifnya yakni rahmatan lil 'alamin. Jadi, sesungguhnya orang Islam adalah orang-orang Nusantara itu sendiri. Tentu saja hal ini tidak menafikan penduduk pedalaman, karena para wali atau penyebar Islam Nusantara justru memilih basis-basis penyebaran Islam di dataran tinggi dan puncak gunung di mana keduanya memiliki kesamaan dalam melihat cakrawala yang luas, modal awal bagi kemampuan berdialektika dan bersifat inklusif sebagai karakter dasar Islam Nusantara.

Kenyataan bahwa Islam yang datang ke Indonesia dibawa oleh para Sufi, menyebabkan Islam pada masa awal-awal banyak berkompromi dengan budaya lokal. Pertemuan Islam dengan budaya lokal ini sering disalah fahami sebagai penyebab kurang murninya Islam Indonesia. Namun perlu ditegaskan bahwa tasawuf yang berkembang diIndonesia adalah tasawuf yang berpadu dengan syariah secara seimbang. Maka tarekat yang berkembang adalah tarekat yang sejalan dengan pandangan itu, seperti tarekat Qadiriyah, Naqshabandiyah, dan Syattariyah. Tarekat ini dianggap mu'tabarah karena memiliki silsilah yang sinambung hingga Nabi Muhammad SAW dan secara isi tidak bertentangan dengan syariat. Beberapa ciri Islam sufistik dapat dikenali dari ekspresi keagamaan Muslim yang masih lestari sampai saat ini. 
Pertama, penghormatan pada guru, baik masih hidup maupun yang sudah meninggal. Penghormatan ini melahirkan tradisi ziarah kubur ke makam para ulama dan wali berkembang subur di kalangan umat Islam Indonesia. Dalam ziarah ini pelaku membacakan tahlil dan tawasul untuk mendoakan arwah ulama atau wali, sebagai orang yang dekat dan dikasihi Allah, agar mereka dimohonkan doa kepada Allah. Selain tawasul, pelaku ziarah juga melakukan i'tibar (mengambil pelajaran) atas perjuangan para wali atau ulama dalam menyebarkan Islam.

Kedua, pembacaan shalawat kepada nabi adalah bentuk tawasul paling murni dari Islam Nusantara. Pembacaan ini telah dimodifikasi sedemikian rupa sehingga lahir berbagai macam sholawat, seperti pembacaan Maulid Nabi, diba', barzanji, shalawat munjiyat, manaqib dan lain-lain. Syeh Burhanddin Ulakan di Minangkabau (murid Syekh Nuruddin Ar-Raniri) menciptakan Sholawat Dulang untuk sarana dakwah. Demikian juga Kiai Manshur Shiddiq di Jawa Timur untuk menghadapi kelompok ateis menciptakan Shalawat Badar. Pembacaan shalawat ini dilakukan di Surau atau Langgar setiap malam Jum'at atau perayaan lahirnya Nabi Muhamamad saw. Bentuk pembacaan itu adakalanya hanya dalam bentuk lisan, tetapi ada yang diiringi dengan beraneka ragam alat musik terutama rebana.

Ketiga, tradisi pembacaan tahlil dan pembacaan al-Qur'an saat ada orang meninggal dunia. Selain dijadikan sarana mendoakan orang Muslim yang meninggal, tradisi ini juga menjadi sarana pelipur lara bagi keluarga yang ditinggalkan, menggantikan kebiasaan zaman pra Islam yang mengisi acara kematian dengan judi dan pesta minuman keras. Tradisi meratapi si mayit oleh para Wali (penyebar Islam di Nusantara) diganti dengan talqin, sementara kebiasaan judi diganti dengan pembacaan zikir dan tahlil.

Keempat, para Wali melakukan kreasi dalam berdakwah dengan menggunakan berbagai sarana misalnya seni wayang atau pemanfaatan 
alat tradisional seperti beduk dan kentongan untuk keperluan ibadah umat Islam. Kedua sarana yang selama ini digunakan sebagai pemberitahuan dan tanda akan diselenggarakan pertemuan atau tanda bahaya (tergantung iramanya) dimanfaatkan oleh Wali untuk memberi tahu tanda dimulainya waktu sembahyang, karena adzan saja yang diteriakkan melalui menara belum cukup komunikatif mengingat jarak antara masjid, langgar atau surau dengan rumah penduduk sangat jauh dan berpencaran. Dengan alat bantu berupa bedug dan kentongan yang suaranya bisa didengar di kampung lain memudahkan jadi penanda telah masuknya waktu shalat. Bahkan ukuran beduk dan panjang kentongan diselaraskan dengan kedudukan masjid atau surau dan langgar. Beduk masjid agung berbeda besarnya dengan mesjid biasa. Alat yang dulunya sekadar sarana bantu, kemudian berkembang sebagai penentu status dari masjid yang bersangkutan, dan selanjutnya ini menjadi perwujudan dari Islam di kawasan Nusantara, sehingga tidak sempurna sebuah masjid yang tidak memiliki beduk yang representative (Mastuki, 2015:1)

\section{Islam Nusantara sebagai Corak Islam Kultural}

Secara obyektif, tidak ada orang yang lahir dari agama, namun setiap orang lahir dari lingkungan 'adat', yang masing-masing mempunyai kulturnya sendiri. Kebudayaan setempat, di mana orang itu dibesarkan, sangat berpengaruh terhadap inkulturasi dan akulturasi keberagamaan seseorang. maka tidak ada orang yang beragama secara murni tanpa dibentuk oleh kulturnya, mereka mengenal dan mengerti agama karena ada yang mengajarkan mereka masalah beragama, pengajaran agama tersebut bisa datang dari orang tuanya, gurunya, kiai-kiai atau bahkan oleh kebiasaan-kebiasaan yang diwarisi begitu saja dari tradisi yang berada di sekitarnya (Abdurrahman, 2003:149).

Indonesia merupakan salah satu di antara sedikit negara di mana Islam tidak menggantikan agama-agama yang ada sebelumnya. Itu 
disebabkan karena proses Islamisasi di Indonesia berlangsung dengan cara yang sering disebut penetration pacifique (penetrasi secara damai), terutama oleh para pedagang-cum-dai (pendakwah). Hasil Islamisasi dengan cara tersebut adalah praktik sinkretisme yang luas dikenal di Indonesia. Salah satu indikasinya adalah sistem penanggalan Jawa, yang mempertahankan asal-usul Hindu kalender Shaka tetapi mengubah sistem penanggalannya dari sistem solar ke lunar, dengan menggunakan nama-nama Arab yang disesuaikan dengan rasa kejawaan untuk menyebut kedua belas bulan: (1) Suro (konversi bahasa Jawa, dalam bahasa Arab disebut As-syura), untuk Muharram; (2) Sapar untuk Shafar; (3) Maulud (dikonversi dari bahasa arab maulid, perayaan kelahiran Nabi Muhammad saw), untuk Rabi' Al-awwal; (4) Bakdo Maulud (dikonversi ba'd al-maulid, 'setelah Maulid'), untuk Rabi' A-Tsani; (5) Jumadilawal, untuk Jumada Al-Ula; (6) Jumadilakhir, untuk Jumada Al-Tsaniyah; (7) Rejeb, untuk Rajab; (8) Ruwah (dikonversi dar bahasa Arab arwah, 'ruh-ruh' kerena kepercayaan rakyat bahwa pada bulan kedelapan ini, ruh orang yang sudah mati akan dibangkitkan kembali dari makam mereka untuk menyambut kedatangan Ramadhan), untuk Sya'ban; (9) Poso (kata Jawa, yang artinya 'puasa'), untuk Ramadhan; (10) Sawal, untuk Syawwal; (11) Selo (kata Jawa yang artinya 'di antara', yakni antara dua hari besar Islam 'Id al-Fithr pada bulan Syawwal dan 'Id Al-Adha pada bulan Dzulhijjah), untuk Dzulqa'dah; dan (12) Besar (kata Jawa yang artinya 'besar', yakni bulan berlangsunganya perayaan hari besar 'Id al-Adha), untuk Dzulhijjah. Kalender Jawa untuk 1993 Masehi adalah 1924 (bukan 1413 H). Pentingnya kalender Islam Jawa ini tidak perlu dibesar-besarkan lagi. Presiden Soeharto sendiri beranggapan bahwa perayaan hari ulang tahun dalam kalender Islam Jawa lebih penting dan secara spiritual lebih bermakna dibanding peristiwa sejenis menurut kalender Barat. Itulah sebabnya mengapa ia merayakan harinya yang istimewa (tumbuk besar), yakni ketika ia mencapai usia yang keenam puluh, menurut perhitungan kalender Islam Jawa, pada 1 Sawal 1915, yang jatuhnya bertepatan dengan 13 Juli 1983 (Abdullah, 1998:94). 
Karena itu, perkembangan kebudayaan Islam di Indonesia sebagian besar merupakan hasil dialog antara nilai-nilai Islam yang universal dengan ciri-ciri kepulauan Nusantara. Clifford Geertz, antropolog Amerika menemukan tiga varian Islam di Jawa, yakni Priyayi, Santri, Abangan.

Meskipun bahasa Arab bukan merupakan satu-satunya sumber dari mana budaya politik Indonesia memperkaya khazanahnya (bahasa Sansekerta, lewat kebudayaan Jawa, juga sangat penting), Indonesia secara keseluruhan, seperti ditunjukkan oleh penilaian Hodgson atas tiga varian Geertz, analisis akhir jelas merupakan sebuah bangsa Muslim. Karena itu, bagi sebagian besar rakyat Indonesia banyak sumber kultural bagi legitimasi politik didasarkan kepada pertimbangan keislaman. Dilihat dari perspektif al-Qur'an, pancasila merupakan titik temu di antara berbagai kelompok agama yang berbeda, yang diperintahkan Allah untuk dicari dan ditemukan. Dengan demikian pancasila menjadi landasan yang kukuh bagi pengembangan toleransi beragama dan pluralisme di Indonesia. Adam Malik yang pernah menjabat sebagai wakil presiden Republik Indonesia menilai bahwa pancasila memiliki semangat yang sama dengan dokumen politik yang dibuat oleh Nabi Muhammad saw bagi masyarakat Madinah, begitu beliau tiba di kota itu setelah berhijrah dari Makkah. Dokumen Madinah itu, yang luas dikenal dengan sebutan 'Piagam Madinah', antara lain berisi penegasan bahwa semua kelompok yang ada di Madinah, termasuk Yahudi adalah bangsa (ummah) dengan kaum Muslim, dan mereka memiliki kewajiban dan hak yang sama dengan kaum Muslim. Adam Malik menafsirkan dokumen itu sebagai rumusan sebuah negara berdasarkan pluraslisme sosial dan keagamaan (Abdullah, 1998:98).

Dalam kenyataan seperti itu, agama tidak lain menjadi identik dengan tradisi. Atau sebuah ekspresi budaya tentang keyakinan orang terhadap sesuatu Yang Suci, tentang ungkapan keimanan terhadap Yang Maha Kuasa. Jika hubungan agama dan tradisi ditempatkan sebagai wujud 
interpretasi sejarah dan kebudayaan, maka semua domain agama adalah kreatifitas manusia yang diyakini setiap orang sebagai yang "benar", pada dasarnya hal itu sebatas yang bisa ditafsirkan dan diekspresikan oleh manusia yang relatif atas "kebenaran" Tuhan yang absolut. Dengan demikian, apa pun bentuk yang dilakukan oleh sikap manusia untuk mempertahankan, memperbaharui atau memurnikan tradisi agama, tetap saja harusdipandang sebagai pergulatan dalam dinamika sejarah umat beragama itu sendiri. Yang seharusnya, hal itu dipandang sebagai fenomena manusia atau sejarahnya, tanpa harus dilihat oleh yang lain, sambil menyatakan bahwa kebenaran yang dimilikinya sebagai yang paling benar (Abdurrahman, 2003:150).

Kreasi budaya yang dipromosikan Walisongo selalu mengapresiasi budaya setempat. Hal itu semua dilakukan oleh Walisongo untuk menghormati budaya setempat tanpa menghilangkan keharusan untuk menginternalisasikan ajaran Islam. Bahkan, penghargaan terhadap tradisi juga masih ada yang berkembang hingga sekarang. Sebagai contoh, larangan Sunan Kudus bagi masyarakat muslim Kudus untuk memakan daging sapi, menurut Abdurrahman Mas'ud, masih dijaga hingga sekarang meskipun mereka mengetahuinya sebagai halal. Hal itu dilakukan sebagai bentuk dari toleransi budaya yang menyatu dalam diri mereka (Suparjo, 2008:1).

Perlu dipahami bahwa akulturasi bukanlah integrasi budaya atau sinkretisme, meskipun dalam batas tertentu hal itu mungkin pula terjadi. Jika dilihat, proses akulturasi yang dilakukan oleh Walisongo bukanlah bentuk integrasi ataupun sinkretisme budaya. Walisongo tidak mengintegrasikan antara kebudayaan Islam dengan kebudayaan lokal, tetapi mereka mengambil instrumen kebudayaan lokal untuk diisi dengan nilai-nilai keislaman. Mereka tidak pula melakukan sinkretisme karena nilai-nilai teologi keislaman tidak dipadukan atau dicampuradukkan dengan nila-nilai teologi lokal. Hal itu sekali lagi dilihat sebagai bentuk 
akulturasi budaya yang dialektis dan dinamis. Maksudnya, Walisongo membangun dan mengembangkan budaya Islam dengan basis kebudayaan lokal (Suparjo, 2008:1).

Islam sebagai agama yang menekankan hubungan dua arah, vertikal dan horizontal, memberikan penegasan bahwa ibadah adalah penerapan dari pemahaman tentang bagaimana umat Islam berinteraksi dengan Sang Pencipta dan bagaimana berinteraksi dengan lingkungan sosial dan lingkungan alam. Proses interaksi yang melibatkan manusia sebagai pelaku utama dalam beribadah di satu sisi, serta Tuhan, lingkungan sosial dan alam di sisi lain memberikan pemahaman bahwa manusia tidak bisa membebaskan diri dari nilai ketuhanan dan nilai lingkungan (lokal, tempat).

Dalam bukunya Raymond F. Paloutzian menegaskan "Intrinsics tend to disagree with statements that suggest a utilitarian motive for adhering to the faith. The intrinsic would also object to the self-serving theme running through the statement. It implies that one is religious strictly so that one can get something out of it, in this case, comfort." Dapat kita lihat bahwa ketika seorang menjalankan agamanya secara intrinsik maka agama akan memotivasi dirinya untuk beramal soleh. Bukan hanya itu saja, seluruh sendi-sendi kehidupannya berjalan sesuai dengan ajaran yang diyakininya, sehingga syariat yang ada dalam ajaran Islam dapat terintegrasi dalam kepribadiannya. Dari sini dapat dilihat proses interaksi antara manusia dengan Tuhannya berjalan sebagaimana mestinya, yang biasa kita kenal dengan istilah 'hablumminallah'. Selain hubungan manusia dengan Tuhannya, seperti yang dijelaskan pada paragraf sebelumnya, ada hubungan manusia dengan lingkungan sosialnya, yang biasa kita sebut hablumminannas, Raymond F. Paloutzian menyebutnya dengan istilah utilitarian yaitu seseorang akan merasa puas atau merasa senang ketika ia dapat membantu sesamanya, ia merasakan hidupnya lebih hidup ketika orang tersebut dapat bermanfaat bagi sesamanya. Dalam persfektif agama Islam beragama semacam ini di 
identikan dengan sikap amal sholeh. Orang yang beramal sholeh mampu menginternalisai nilai-nilai agama kedalam ranah kesadaran spritual dan sosial

Pada titik ini, pertemuan antara Islam sebagai nilai yang berasal dari Tuhan dan nilai lokal dapat dilihat sebagai perwujudan dan hasil dari interaksi manusia dengan lingkungan setempat yang menghasilkan perilaku atau aktivitas termasuk yang bersifat keagamaan atau keislaman. Ritual-ritual ibadah terutama yang menyangkut muamalah ma'a alnas (interaksi seseorang atau masyarakat Muslim dengan lingkungan sosial maupun lingkungan alam) tidak luput dari bagaimana manusia memperlakukan orang lain atau lingkungan dalam kehidupan sehari-hari (Salom, 2016:1).

Bagaimana memperlakukan orang lain dan lingkungan atau dalam bahasa lain pola interaksi antara manusia dengan manusia dan manusia dengan lingkungan sangat dipengaruhi oleh nilai-nilai dan hasil kombinasi antara Islam dengan budaya dan kearifan lokal. Itulah yang menjelaskan mengapa ekspresi dan ritual keagamaan mencerminkan integrasi nilai dan ajaran Islam dengan nilai lokal.

Integrasi tersebut dimungkinkan terjadi bila kita merujuk kepada konsep al-urf dan al-maslahah al-mursalahdalam kaidah ushul fikih. Pengakuan dan penggunaan kedua konsep tersebut oleh para ulama manunjukkan bahwa tradisi dan kemaslahatan menjadi sumber pertimbangan dasar dalam menentukan hukum. Hal itu menjadi argumen lain yang menguatkan bahwa nilai lokal mendapatkan kedudukan yang terhormat dalam kehidupan keagamaan umat Islam.

Nurcholis Madjid (dalam Salom, 2016:1) menjelaskan bahwa alQuran dan Hadis Nabi sangat mengakomodir nilai-nilai lokal. Misalnya ia berargumen bahwa penyebutan kata 'al-ma'ruf' sebagai yang seakar dengan al-urf mengandung pengertian nilai-nilai kebajikan atau tradisi baik yang dikenal banyak orang. Jadi, kebajikan dan keberagamaan adalah 
sesuatu yang mengandung nilai kebaikan yang diketahui dan diakui oleh banyak orang. Dengan kata lain, kebajikan dan keberagamaan adalah nilai yang bersifat konstruktif secara sosial-budaya.

Menjadi Muslim berarti kesadaran untuk mematuhi semua ajaran Islam sebagaimana yang tertuang dalam al-Quran dan as-Sunnah, namun persoalan muncul ketika seseorang menyadari dirinya sebagai Muslim di satu sisi, dan pada saat yang bersamaan sekaligus sebagai warga masyarakat dan bangsa. Sebagai warga masyarakat yang mendiami lokalitas tertentu dengan identitas etnis dan budaya tertentu, seorang Muslim sudah barang tentu selalu melakukan dialog diri antara keimanannya akan nilai-nilai agamanya dengan realitas sosio-kultural masyarakatnya. Dengan demikian, praksis keagamaan seseorang sesungguhnya selalu merefleksikan suatu peragaan kulturalnya. Inilah dasar mengapa studi tentang kebudayaan, selalu berarti kesiapan untuk terbuka terhadap nilai-nilai spiritualitas agama karena kebudayaan dalam lapisan terdalamnya selalu menjadi lokus bagi peragaan spiritualitas seseorang bersamasama komunitasnya. Demikian juga dalam setiap studi tentang agama, seseorang harus terbuka terhadap dimensi kultural yang mengiringi semua praksis keagamaan (Abadi, 2012:2).

Dalam jurnal yang disamapaikan Khabibi Muhammad Luthfi ada 3 ungkapan yang menunjukkan budaya lokal memengaruhi Islam, sehingga berpenngaruh terhadap cara berislamnya masyarakat Indonesia, Jawa khususnya. Pertama, Islam adalah agama yang datang ke nusantara dengan tujuan mengislamkan masyarakatnya. Islam hadir untuk memengaruhinya. Ini dapat dilihat dari ungkapan yang menjelaskan Islam Nusantara sebagai konsep bahwa Islam dengan nilainilainya itu yang mempengaruhi. Mirip dengan kaidah dalam kitab fikih, fath al-Mu'in; yang mendatangi itu lebih diunggulkan daripada yang didatangi. Dalam hubungan ini, budaya yang dibawa Islam untuk memengaruhi Nusantara adalah sistem nilai subtantif atau universal, 
teologi, dan ritual Ibadah yang sifatnya pasti. Sementara budaya Islam yang bersifat fisik-dalam pengertian sosiologis-seperti cara berpakaian, berjilbab, dan nada membaca al-Quran (langgam) dianggap sebagai budaya Arab yang tidak perlu dibawa ke Nusantara. Konsep inilah yang ditonjolkan Islam Nusantara sebagaimana dijelaskan Moqsith (sebagai metodologi) dengan ungkapan 'melabuhkan'. "Islam Nusantara datang bukan untuk mengubah doktrin Islam. Ia hanya ingin mencari cara bagaimana melabuhkan Islam dalam konteks budaya masyarakat yang beragam. Islam nusantara bukan sebuah upaya sinkretisme yang memadukan Islam dengan agama Jawa, melainkan kesadaran budaya dalam berdakwah sebagaimana yang telah dilakukan oleh pendahulu kita walisongo." Kedua, pada tataran ini Islam dan budaya Indonesia dalam posisi seimbang. Islam merasa sejajar dengan budaya lokal bisa dimaknai tiga pengertian. (1) Islam memiliki budaya fisik-sosiologis yang memilki karakteristik kearaban bisa digabung dengan budaya lokal, sehingga memunculkan budaya baru. Misalnya, lembaga pendidikan pesantren dan tulisan pegon (gabungan dari budaya tulisan Arab dengan bahasa Nusantara). Mahrus mengungkapan adaptasi. Selanjutnya, (2) Islam dan budaya lokal seimbang dalam wilayah nilai-nilai universal. Sebagimana dijelasakan Ishom Syauqi, bahwa Islam Nusantara hendak mewujudkan budaya dan peradaban baru dunia yang berbasis pada nilai-nilai luhur dan universal keislaman dan kenusantaraan. Di sini, nilai Islam dan kenusantaraan sejajar, sehingga keduanya menghasilkan peradaban baru. (3) Islam merasa sejajar dalam wilayah teologis (sistem kepercayaan) dan peribadatan dengan budaya lokal, tetapi di antara keduanya tidak ada saling sapa melainkan saling menghormati atau toleransi. Ini dibuktikan dengan adanya UUD dan Pancasila yang dijadikan sebagai dasar negara Indonesia. Argumentasi yang cukup komprehensif diungkapkan oleh Musthofa Bisri dengan ungkapan toleransi: "Islam Nusantara yang telah memiliki wajah yang mencolok, sekaligus meneguhkan nilai-nilai harmoni sosial dan toleransi dalam kehidupan masyarakatnya, Negara Kesatuan 
Republik Indonesia berdasarkan Pancasila dan Undang-undang Dasar 1945 serta bersendikan Bhinneka Tunggal Ika, secara nyata merupakan konsep yang mencerminkan pemahaman Islam ahl as-sunnah wa aljama'ah yang berintikan rahmat. Ketiga, budaya lokal memengaruhi Islam. Budaya Indonesia sebagai 'tuan rumah' aktif dalam menjaga, memberi tempat, dan membina Islam agar tidak berbenturan. Ini menunjukkan bahwa ketika masuk dalam budaya lokal, Islam diletakkan dalam posisi tertentu sehingga tidak memengaruhi unsur-unsur budaya Nusantara. Ibarat rumah, Islam hanya diperbolehkan masuk ke kamar tertentu tetapi dilarang masuk kamar lain.

\section{Simpulan}

Setelah dipahami mengenai Islam nusantara maka bisa ditelusuri bahwa Islam Nusantara merupakan agama yang ramah dengan budaya. Orang ber-Islam secara kaffah namun tidak meninggalkan tradisi-tradisi kebudayaannya, justru tradisi atau kebudayaannyalah yang membuat mereka semakin kuat dan percaya dengan agama yang diyakininya.

Dalam Islam nusantara terdeskripsikan bagaimana ajaran yang secara normatif berasal dari Tuhan diakomodasikan ke dalam kebudayaan yang berasal dari manusia tanpa kehilangan identitasnya masing-masing. Dengan demikian, Arabisasi sebagaimana telah ditegaskan adalah belum tentu cocok dengan kebutuhan. Islam Nusantara berusaha menjadikan agama dan budaya tidak saling mengalahkan, melainkan mewujud dalam pola nalar keagamaan yang tidak lagi mengambil bentuknya yang otentik dari agama serta berusaha mempertemukan jembatan yang selama ini memisahkan antara agama dan budaya, sehingga sudah tidak ada lagi pertentangan antara agama dan budaya. Sebagai contoh, para Wali di Jawa berusahamemperkenalkanIslam melalui tradisi, sehingga mereka perlu mempelajari kekawian (sastra klasik) yang ada serta berbagai seni pertunjukan, yangdari itu terlahir berbagain serat atau kitab. Wayang 
yang merupakan ritual agama Hindu yang politeis diubah menjadi sarana dakwah dan ajaran monotheis. Ini merupakan kreativitas tiada tara, sehingga seluruh lapisan masyarakat mulai petani pedagang hingga priyayi dan bangsawan dapat diislamkan melalui jalur ini. Mereka merasa aman dengan hadirnya Islam, karena Islam hadir tanpa mengancam tradisi, budaya dan posisi mereka.

\section{Daftar Pustaka}

Abadi, Mashur. 2012. "Islam, Budaya Lokal dan Kedewasaan Berbangsa." Karsa: Jurnal Sosial dan Budaya Keislaman 13, no. 1

Abdullah, taufik dkk. 1998. Jalan Baru Islam Memetakan Paradigma Mutakhir Islam Indonesia. Bandung: Mizan

Abdurrahman, Moeslim. 2003. Islam sebagai Kritik Sosial. Jakarta: Erlangga Ali, Mukti dkk. 2004. Metodologi Penelitian Agama suatu Pengantar. Yogyakarta: Tiara Wacana Yogya

Azra, Azyumardi. 1995. Jaringan Ulama Timur Tengah dan Kepulauan Nusantara Abad XVII dan XVIII. Bandung: Mizan

Imam Subqi, "Pola Komunikasi Keagamaan dalam Membentuk Kepribadian Anak", INJECT (Interdisciplinary Journal of Communication), Vol 1 No 2 Desember 2016.

Imarah, Muhammad. Islam dan Pluralitas Perbedaan dan Kemajemukan dalam Bingkai Persatuan. Jakarta: Gema Insani Press

Karim, Abdul. 2007. Sejarah Pemikiran dan Peradaban Islam. Yogyakarta: Pustaka Book Publisher

Luthfi, Khabibi Muhammad. 2016. "Islam Nusantara: Relasi Islam dan Budaya Lokal." SHAHIH: Journal of Islamicate Multidisciplinary 1, no. 1

Paloutzian, Raymond F. 1996. Psychology of Religion. Massachusetts: Allyn \& Bacon

Qomar, Mujamil. 2016. "Islam Nusantara: Sebuah Alternatif Model Pemikiran, Pemahaman, dan Pengamalan Islam." El-HARAKAH (TER- 
INJECT: Interdisciplinary Journal of Communication, Vol.2, No.1, Juni 2017: h. 27-52

AKREDITASI) 17, no. 2

Sahed, Nur, dan Musari Musari. 2016. "The Discourse of Islamic Education Development Based on Islam Nusantara Concept in IAIN Salatiga." Jurnal Pendidikan Islam 5, no. 1

Suparjo, Suparjo. 2008. "Islam dan Budaya: Strategi Kultural Walisongo dalam Membangun Masyarakat Muslim Indonesia." KOMUNIKA 2, no. 2

Susanto, Edi, dan Karimullah Karimullah. 2017. "Islam Nusantara: Islam Khas dan Akomodatif terhadap Budaya Lokal." Al-Ulum 16, no. 1

Wahid Abdurrahman, dkk. 2016. Islam Nusantara. Bandung: Mizan

Wahjoetomo. 1979. Pendidikan Alternatif Masa Depan. Jakarta: Gema Insani Press.

Zuhaili, Muhammad. 2002. Pentingnya Pendidikan Islam Sejak Dini. Jakarta: AH. Ba'adillah Press. 